\title{
TEMPORAL COORDINATES AND THE DEICTIC CENTRE IN SULA BY TONI MORRISON
}

Linas Selmistraitis, Mykolas Romeris University, Lithuania

Violeta Janulevičiene, Mykolas Romeris University, Lithuania, , vjanul@mruni.eu

DOI: 10.31902/fll.36.2021.13

\begin{abstract}
The present study deals with the role of lexical and grammatical text coherence devices in the text-constructing process and in maintaining chronological organization of the text. These devices safeguard against the disruption of the continuum in the elliptical fragmentary narrative of a Nobel Prize-winning author Toni Morrison's short novel "Sula" where the narration weaves forward and backward, departing from the linear chronological sequence of events. "Sula" (1973) is one of the first black feminist novels in the United States, due to the current social movements sparkling a renewed interest in the story. The author herself described it as a "cracked mirror", the pieces of which should be assembled by the reader. Methodology of the research is based on qualitative approach, the main methods being descriptive, analytical and structural-narratological. The analysis of the whole text corpus of the novel is followed by the description of the obtained data, highlighting predominant temporal devices employed in retrospection, prospection and the deixis of the narration, the continuum of narration and the overall structuring of the plot. The paper describes in detail recurrent integrative devices related to the chronological organization of the text - deictic center, specific verb tense usage, time adverbials and the overall semantics of the situation. The study shall contribute to the development of specific aspects of chronological organization of the text in the general theory of text linguistics and could be a feasible aid in teaching practical literary analysis and creative writing by providing inventory of the temporal coordinates and by developing learners' skills for the analysis and reconstruction of the fragmented text continuum.
\end{abstract}

Keywords: chronology of the non-linear narration, temporal coordinates, deixis.

\section{INTRODUCTION}

The aim of the present study is to identify the role of lexical and grammatical time-expressing devices in chronological text organization of Toni Morrison's novel "Sula". The narration of the novel does not follow a linear way. As the author herself put in one of her interviews: 
"In larger terms, I thought of Sula as a cracked mirror, fragments and pieces we have to see independently and put together" (LeClair). The narrative of the novel weaves backwards and forwards, departing from the linear sequence of historical order. Therefore, it is considered important to establish which lexical and grammatical structures safeguard against the disruption of a continuum.

The object of the research is the corpus of the whole text, consisting of 2982 sentences. A functional-semantic approach to text analysis offers a revealing look at various resources of language in the creation of meaning (Halliday and Webster 2014) and the reason for the whole text analysis is based on the indication that "the best way to learn about text linguistics is through the analysis of full texts" (ibid., 22).

The topicality of the aim is determined, mainly, by two factors. Firstly, it is considered important to survey the text continuum devices for their role in the text-constructing process since the text level structure governs sentence relations and their lexical and grammatical valency. Secondly, the research of text devices as means for maintaining chronological organization of the text and functioning as text message conveying ideas is still scarce.

The following objectives have been set: 1) to peruse research on temporal characteristics of narratives and to describe predominant lexical and grammatical temporal coordinates; 2 ) to analyze and present the way lexical and grammatical time-expressing devices organize time sequencing of the fragmented fabula in the novel "Sula". To the best knowledge of the authors, the text "Sula" has not been analyzed before from the point-of-view of chronological text organization. Therefore, it is assumed that the research on temporal characteristics of this text would contribute to pointing out the prevailing tendencies on predominant temporal means and devices used in a literary text.

Methodology of the research is based on qualitative approach, the main methods being descriptive, analytic and structural-narratological. The theoretical part overviews publications on cataphorical, anaphorical temporal characteristics of the text and deixis. The empirical part of the paper encompasses the analysis of the whole corpus of the short novel "Sula" by T. Morrison. The description of the data obtained highlights specific temporal devices that are employed in retrospection, prospection and the deixis of the narration, the continuum of narration, interrupted narration and the overall structuring of the plot. Description emerges following creative exploration and serves to organize the findings together with fitting explanations.

The paper presents only the most significant and recurrent patterns of chronological structuring of the novel. The fragments cited stand for 
deliberately chosen blocks of the text structure in terms of its continuum. Several fragments with a switch of the temporal deictic center observed are given special prominence.

The theoretical and practical value of the present study is in verification of the time expressing devices as text-building structures. It is believed to contribute to the development of specific aspects of chronological organization of the text in the general theory of text linguistics. This study could be a feasible aid in teaching practical literary analysis and creative writing by providing inventory of the temporal coordinates and by developing learners' skills for the analysis and reconstruction of the fragmented text continuum.

\section{ON THE RECENT RESEARCH OF TONI MORRISON'S "SULA"}

The choice of the novel for the present study is predetermined by several factors: with the recent global powerful social movement "Black Lives Matter", there is a surge to investigate literary creations by African-American novelists which are yet less-known for some contingent of students. "Sula", written in 1973 by a Nobel Prize-winning author Toni Morrison, is an influential first black feminist novel in the United States. In "Sula", Morrison develops multidimensional female characters and through them explores themes of friendship, gender, and race. The manner of novel narration is quite specific as well, i.e. it does not develop in a linear chronological way.

Recently, the short novel "Sula" has sparkled a renewed interest among researchers and has been analyzed from different perspectives: as a manifestation of the tensions of a racially-prejudiced America and the dire consequences for the black community and self through the depiction of the madness of the homecoming traumatized African American war veterans (Lopez-Ramirez 129-135); emasculation system in order to provide deeper understanding to Toni Morrison's skills to deal with the conditions of Blacks in the South of the USA (Kpohoue 2025); as a presentation of the discourse of motherhood and the motherdaughter relationships (Kitanovska-Ristoska 301-317); or analysis of the female relationships - mothers and daughters and friends - as a continual search for sisterhood (Fetters 28-55). "Sula" confronts issues of loyalty, family, assimilation, innocence, gender, and sexuality, but many critics agree that at its heart is "an examination of the priorities that determine the character, quality, and relationships of a woman's lifetime" (Mambrol 1). Ultimately, "Sula" has been seen as a debate instigation on whether individual experience or general ethic principles are foundations for personal ethics (Nissen 265). 
Though mentioned studies focus on different sections and undercurrent themes of "Sula", almost every scholar notes a complex modernist and experimental narrative that places on the reader additional challenge for interpreting. McDowell (68-69) aptly observes: "Whatever coherence and meaning resides in the narrative, the reader must struggle to create", because the textual unity in this novel is disrupted by fragmentary, episodic, elliptical quality. Bouson (159) goes further in contemplating the reason for it and points out that modern trauma novels "employ a nonlinear plot or disruptive temporal sequences to emphasize mental confusion, chaos, or contemplation as a response to the [traumatic] experience". In Morrison's writings, her fragmentary story-telling is the most striking formal characteristics (Peach 102). This structural feature is manifested in elliptical narratives with many gaps in the narration that are difficult for the readers (particularly, novice readers, as students) to fill in.

It is assumed that the research on temporal characteristics of this text would contribute to pointing out the prevailing tendencies on predominant temporal means and devices used in a literary text.

\section{ON THE DIVISIBILITY AND COHERENCE OF THE TEXT}

Introspection of the formal and semantic textual structures calls for an overview of the full picture of architectonical and compositional temporal characteristics. Two categories of the text - divisibility and cohesion/coherence - are inalienable to the text (Tardy, Swales 693). They are present in the text as symbiotic, mutually dependent phenomena.

In the second half of the $20^{\text {th }}$ century, the peculiarities of the functioning of a sentence in the text were taken into consideration, i.e. linguists turned to the functional significance of the sentence and started considering it as fundamental alongside the structural one, stepping out of the boundaries of a sentence. This led to detailed research in the field of relations between sentences which form the text.

One of the specific text categories is "continuum" - a continuous flow in time and space. A sentence is, in most cases, static, it does not have dynamics. Divisibility and coherence of the text are directly connected to the effect of centrifugal and centripetal forces in it (Ladin 133). On the one hand, the text implies different lines of the plot, intersection of topics, changing of points of view with the devices of different styles and registers introduced. Thus, in case centrifugal forces dominate, the text becomes shredded. On the other hand, everything is subordinated to one main task. Different segments scattered in the text are connected by one theme or one character, by one continuum of 
place and time that represent centripetal forces of the text creation (ibid. 132).

The inseparable unity of centrifugal and centripetal forces of the text is maintained also by such imminent text categories as prospection and retrospection. These categories develop the plot in two different ways: prospection develops the plot forward, cataphorically; retrospection develops the plot backward, anaphorically.

Prospection and retrospection can be distinguished only against the background of currency, i.e. the moment which is the current point of reference, the point which serves as "the point of departure" for the events which are described in the text. This point of departure is referred to as the deictic center of the narration, i.e. "the time line in fictional narratives is bounded by the time frame in which the narrative events take place" (Sanders and van Krieken 281). The deictic center does not coincide with the present time, it depends on the point of time reference the narrator chooses in the text. Retrospection and prospection can be distinguished in the cases when the narration is carried out in contrast with the deictic center, either by anticipating the events or narrating retrospectively.

"The term deixis (which comes from a Greek word meaning "pointing" or "indicating") is now used in linguistics to refer to the function of personal and demonstrative pronouns, of tense and a variety of other grammatical and lexical features which relate utterances to the spatio-temporal co-ordinates of the act of utterance" (Lyons 636). These person, place and time coordinates originate at deictic center (Grundy 22). In this paper, temporal coordinates of deictic center are researched, in as much as they stipulate the chronological organization of text. The deictic center is an appropriate and useful data structure for representing and integrating the information in narrative and is thus a useful construct for studying how separate sentence interpretation is integrated into more global comprehension of the whole text (Dancygier 399).

Interweaving of times of narration presupposes segmentation of the text. The more chaotic relation in terms of time is spotted between events, the more difficult the fabula is perceived. Retrospection and prospection stop linear progression of time. These two forms violate and disturb place and time continuum (Volkova 380). However, even in such cases because of the cohesive and coherent nature of the text, a particular fragment of the text fluently flows into a textual net and forms a semantic bridge which connects the previous and the following narration. In many texts, prospection and retrospection are perceived implicitly, i.e. they are semantically based on either earlier action, or 
foreshadow the forthcoming events. The time of the fiction world constantly changes; it is unstable, and it undergoes mutation. That is the reason why in the texts of belles-lettres the linear, chronological, historical order of time is broken.

\section{CHRONOLOGICAL ORGANISATION OF "SULA'S" NARRATION AND MEANS OF ITS ENUNCIATION}

Events that carry temporal core of any narrative are linguistically and conceptually constrained. The point of time reference or a temporal deictic center is useful for integrating and representing the information in a narrative. Since temporal relations between events are not always expressed, the reader needs a mechanism for deriving them. Many factors usually operate together within a narrative to indicate the temporal relation between the events and to make the text coherent. Among these factors are the point of time reference - deictic center, tense, time adverbials, even the general common sense, which construe the chronological organization of a text.

Time indication in "Sula" has two deictic centers: the deictic center of the narrator and the deictic center of characters.

This study delves into the consecutive analysis of chapters, however, it makes explicit that specific time indication of the chapter titles does not necessarily limit happenings within the prescribed time period, i.e. the events sequence is anchored to the deictic center.

The first four paragraphs of the novel "Sula" present the narrator's point of time reference. The narrator is temporally located in the present and carries out the narration from the current moment. The point of time reference is the present, it coincides with the moment of narration and follows the structure me-here-now. In Sentence 3 the narrator's deictic center - now - is indicated and the narration is constructed from this perspective:

In that place, where they tore the nightshade and blackberry patches from their roots to make room for the Medallion City Golf Course, there was once a neighbourhood. It stood in the hills above the valley town of Medallion and spread all the way to the river. It is called the suburbs now, but when black people lived there it was called the Bottom.

The past tense verbs "tore, was" obviously indicate the past events in Sentence 1 . The adverb of time "once" indicates that the events happened at some unspecified time in the past. The events are not temporally homogenous, i. e. they are not located in a linear progressive sequence. Past events are preceded by other past events. The tense 
system in the first paragraph is varied: past simple "tore, stood, lived", present simple "is called, are gone", present perfect "have been allotted", future "will knock", present continuous for future plans "are going." Thus, the omniscient narrator shifts the narration backwards and forwards. At the end of this chapter the author prepares the reader for the more distant past events, to be revealed in a new chapter:

The black people would have disagreed, but they had no time to think about it. They were mightily preoccupied with earthly things and each other, wondering even as early as 1920 what Shadrack was all about, what that little girl Sula who grew into a woman in their town was all about, and what they themselves were all about, tucked up there in the bottom.

Here the time adverbial 1920 is specified. The narrator retrospectively goes back from the current events in the 70 -ies of the $20^{\text {th }}$ century to the events which happened in the past at a definite time, indicated by the time adverbial 1920. Obviously, the time continuum with the previous passage is violated. At the same time this paragraph forms a semantic bridge which connects the previous and the following narration. Firstly, it is achieved through the coherence of the text: substitute it (had no time to think about it) embraces the narration of the previous paragraphs about the origin of the name the Bottom. The semantic relation with the following paragraphs will be maintained through the introduction of new characters names whose role in the plot of the novel will be significant, i.e. Shadrack and Sula. Thus, the semantic connection of two sentences serves against disruption of the fluency of a textual stream. The narrator sees the events which will be revealed from the narrator's particular time reference point. This retrospection discloses new information related to the past, and it will be essential for comprehending the upcoming events. The subsequent events construct the main plot of the novel. It must be noted that the whole narration has a linear character in terms of time and is placed on time axis beginning with the year 1919 and finishing with the year 1965 . The following chapter, "1919" leads to the assumption that the main part of the events described in this chapter happened in the year of 1919. The semantic radius of the title should stretch throughout the whole chapter. However, the temporal expanse of the novel is wider than the title of the chapter indicates, as seen from the first paragraph:

Except for World War II, nothing ever interfered with the celebration of National Suicide Day. It had taken place every January third since 1920, although Shadrack, its founder, was for many years the only celebrant. Blasted and permanently astonished 
by the events of 1917, he had returned to Medallion handsome but ravaged [...]. [...] Shadrack had found himself in December, 1917 $[\ldots]$.

Obviously, the very beginning of this chapter diverts from 1919. In the first sentences of this paragraph, even four different temporal indications are mentioned. They are time adverbials: World War II, January the third, since 1920, December 1917. In the text structure, the years of World War II are just a transition point during which the settled course of events ("the celebration of National Day of Suicide") was disturbed. In the following sentence, the narrator starts revealing the details of the forming events in December 1917. The author retrospectively goes back from the current point of reference 1919 to the year 1917 to disclose those life details of Shadrack's life which had happened in the past but are vital for understanding the following narration:

A young man of hardly twenty, his head full of nothing and his mouth recalling the taste of lipstick, Shadrack had found himself in December, 1917, running with his comrades across a field in France.[...]For several days they had been marching, keeping close to a stream that was frozen at its edges.[...]Before he [Shadrack] could register shock, the rest of the soldier's head disappeared under the inverted soup bowl of his helmet.

The narrator uses the past perfect tense ("had found himself, had been marching, had stepped") to point out the events before the year 1919. In this case, two means of realization of retrospection are involved: time adverbial ("December 1917") following the past perfect tense indicators that ensure the cataphoric use of the definite past perfect tense.

The forthcoming events logically follow the previous ones: after being injured in the battle, Shadrack appeared to be in the hospital. Here we observe the principle of cumulative cohesion. Cohesive devices tend to be redundant in text. There are intervals of uncertainty during which it is unclear whether time has been shifted. Absence of temporal devices correspond to the interval of uncertainty in the text, but semantically the reader makes the inference that Shadrack appeared in the hospital after the attack and the events are presented following the laws of linear time direction. Reversing the order of the sentence would reverse the order of events.

Shadrack left the hospital after "the long stay". This noun phrase subjectively presents the time period because the notion long is 
relevant. It is presented from the narrator's point of view and cannot be put on the scale of time for measuring. It is worthwhile to note that in the previous text there was some reference to the winter season. From the lexical time indicators the cropped shrubbery, the edged lawns, green grass, it can be assumed that during Shadrack's stay in hospital the season of the year had changed: it might be late summer or autumn. Hence, time can be deduced without time adverbials through lexical means. Later in the text, the exact time span is indicated:

He trotted quickly to it and left, a heaven of more than a year, only eight days of which he fully recollected

Thus, Shadrack's stay in hospital continues from December 1917 till the summer of 1919. Now the reader can recollect the previous text and join the information, which was already presented in the text above: Shadrack recovered consciousness after a long illness only in 1919. The analysis of the extract points to the possibility to indicate temporal coordinates at the end of a particular event report and thus direct to the previous narration.

The duration of events in the text can be defined with different precision ranging from the proximity of hours to a year, determined by the author's purpose to reveal details which are relevant to the structure of the plot. The chapter "1921", as well as the previous one, is structured in such a way that the narrator deliberately shifts back from the deictic centre, which is the year 1921. It is shown by some lexical phrases, verbs, time adverbials and the logical structure (or semantics) of the events. The events of this chapter are mostly related to Sula's grandmother Eva. She is the character that helps to make the text semantically coherent. Shifting of the time forward and backward is obvious:

The creator and sovereign of this enormous house [...] was Eva Peace, who sat in a wagon on the third floor directing the lives of her children [...] Fewer than nine people in the town remembered when Eva had two legs [...]. Eva had married a man named BoyBoy and had three children [...]. After five years of a sad and disgruntled marriage BoyBoy took off. When he left in November, Eva had \$ 1.65 [...]. She was confused and desperately hungry.

The author goes far back into the past when Eva was just married. Meanwhile, from the point of the current deictic center she is already a grandmother. Thus, the events which happened before the current time are indicated by the past perfect. The retrospectively presented episodes of Eva's life have their inner temporal structure, they are lined up by the adverbials "after five years, in November," and then further in 
the passage "in December, sometime before the middle of December, two days later, eighteen month later". Some of these adverbials are indicators of cyclic time - the winter.

From 1921 the narrator moves again back and retrospectively speaks about the events which took place before 1921. Retrospection puts some new accents in the text. It is the reader who has to keep in memory some facts, characteristics, time and place and the reader has to work out the sequence of events as the events of the distal past are related to the events of the present narrator's time.

Evidently, it is the deictic center of the narrator that serves as a cohesive device of the novel, despite the varied usage of adverbs of time, varied tense system, shifts in text semantics and constant change of retrospection and prospection within the same passage.

In the exchanges of the characters, the events are presented from a character's point of time reference. The narrator's presence in the dialogues is demonstrated through sporadic remarks, however, all of them are in the past tense form: "someone said, the friend answered, some lover said, his sweetheart answered". Thus, from the narrator's point of view the dialogue took place in the past. However, to achieve the effect of a live exchange between characters, the point of time reference is shifted from the narrator's, which is in the past, to the present moment of the character's deictic center.

Similarly, Chapter "1920" opens with the events which happened long before this particular year. The narrator does gradually come to the events of November 1920, and it becomes the deictic center of the narration. Helen's and Nel Wright's arrival in New Orleans is not directly indicated by time adverbials, nor is the durance of their journey. The time adverbial in the following sentence retrospectively joins the previous text to the current events:

...Blotting her lashes with a white handkerchief, Helen walked through the kitchen to the back bedroom where she had slept for sixteen years.

Thus, time indication "for sixteen years" is a bridge which joins in the reader's memory the information presented retrospectively in the previous paragraphs. The narrator presents the facts about the character gradually. The sentence "She's is ten now" in the dialogue, which takes place in New Orleans, allows the reader to realize the span of time covered retrospectively. It does require a conscious effort, but it could be inferred by calculation that this "1920" chapter begins with the 35 year old events. Interestingly enough, these retrospective events are 
followed by an instance of prospection: It was the last as well as the first time she was ever to leave Medallion[...].

Thus, the narrator prospectively highlights that Nel will never leave Medallion. The prospective flash-forward relates this fact to ones revealed in the following parts of the text but it does not disclose the development of future events. This flash-forward just intensifies the reader's attention.

The title of chapter "1922" prospectively outlines time boundaries. The beginning of the chapter has no other time indicators. Thus, the inferences may be made that the episode is related exactly to the time indicated by the title of the chapter. However, temporal coordinates are not the sole indicators for the chronological organization of the text. The space indicators are also important to orientate a reader in time flow. It is obvious in the following extract from the beginning of the chapter "1922":

Nel and Sula walked through this valley of eyes chilled by the wind and heated by the embarrassment of appraising stares. [...] Long before Edna Finch's Mellow House opened, even before they marched through the chocolate halls of Garfield Primary school out onto the playground [...] When Nel, an only child, sat on the steps of her back porch surrounded by the silence...

The lexical items indicating locality are different. At first, the action takes place in a valley of eyes chilled by the wind, later - chocolate halls of Garfield Primary school, and at last - on the steps of her back porch. These adverbials signal the different locality, thus, a change of the locality indirectly indicates that the time is also different. The narrator can shift the time reference without resorting to specific time-indicating means.

In chapter "1923", semantic importance of this particular year indication in the title continues until another temporal coordinate is presented. The chapter begins with a dialogue between Hannah and her mother Eve and it is anchored to the deictic center, the year 1923, however, semantically their conversation touches upon events which happened before 1923. At first, there is no definite time indication. Later in the dialogue it is revealed:

I'm talkin' 'bout 18 and 95 when I set in that house five days with you and Pearl and Plum and three beets, you snake-eyed ungrateful hussy.

This dialogue is retrospective and joins current chapter to the events described in "1920". Only at this point, a reader infers the exact 
date of their occurrence. Thus, the signals of time are scattered in different chapters and later join separate recurrent episodes. The recurrent episodes are presented from different points of view and contribute new details to the characters and develop the idea of the novel.

After the analyzed dialogue the narration returns to the year 1923 since the time adverbial now signals the current deictic center: Hannah had enough beans now. This sentence indicates the narrator's deictic center, though grammatically this current moment is expressed by a past simple tense.

"Part two" of the short novel begins with the chapter "1937". Similar to the previous chapters, when the time was indicated in the title of the chapter, the events are centered around this year. The temporal space between the previous and the current chapter is 10 years. Thus, the period of ten years is skipped. The following episode is unique in the structure of the text. It is Nel's monologue which can be assumed as a specific way of temporal expression in the text. Nel's monologue is not used in quotation marks. Thus, one of the main characters becomes the narrator. The narrator Nel moves in time back and forth. At first, she refers to Sula and her husband's adultery, an event which happened in the past. Then, she transfers herself into the middle of the described events and depicts them as occurring at present using the present tense. In this narration, different tense forms change one another:

But they had been down on all fours naked [...] and when I opened the door they didn't even look for a minute and I thought the reason they are not looking up is because they are not doing it. So it's all right. I am just standing here. They are not doing that. I am just standing here and seeing it, but they are not really doing it. But then they did look up.

Here, the coherence of the episode presented from different time perspectives is maintained through semantics of a micro-topic. Nel's narrative fluently merges with the narrator's. Returning to the narrator's temporal deictic center is marked by a definite time indicator:

The clock was ticking. Nel looked at it and realized that it was two thirty, only forty-five minutes before the children would be home [...].

However, this time indication spans just a few following sentences, in which Nel's ideas of her past are conveyed.

It should be noted, that sign-posting adverbials for sequencing the events are used scarcely in the novel. Only in one paragraph of Chapter 
"1939", describing the events occurring after two years. Such linking devices as later, at first, finally are implied to present actions happening one after another:

Later, after the word got out, Ajax and two other men went to the station to see about him. At first they wouldn't let them in. But they relented after Ajax and the other two just stood around for one hour and a half and repeated their request at regular intervals. When they finally got permission to go in and looked in at him in the cell, he was twisted up in a corner badly beaten and dressed in nothing but extremely soiled underwear.

Chapter "1940" is characterized by an exceptionally small number of time adverbials. It describes the events which are lined up chronologically and there is only one adverbial this year. The chapter contains the description of the characters' feelings, their conversations about the past prevail. Therefore, it is more important what happened than when. The narrator uses the time adverbial now although past time events are described. Chapter "1940" ends with Sula's death and next chapter "1941" begins with the description of Sula's funeral, the same micro-topic bridging two chapters.

The last chapter "1965" distances from the previous temporal deictic center by the period of 25 years. This period in the characters' lives is skipped in the text:

Things were so much better in 1965. Or it seemed so. You could go down town and see colored people working in the dime store behind the counters, even handling money with cash-register keys around their necks.[...] They were so different, these young people. So different from the way she remembered them forty years ago. Jesus, there were some beautiful boys in 1921!

However, starting with the second paragraph, the narration goes 40 years back. There is a semantic bridge between the retrospective narration and the deictic center of 1965 . The third paragraph is retrospective because the recollection of the events in the third paragraph is related to the year 1921. There is some inaptitude in terms of the temporal flow of time. Thus, the narrator freely moves in the temporal space of the text. However, the following sentence again returns the narration into the temporality of the narrator's deictic center: These modern day whores were pale and dull before those women. Further in the text, there is constant shifting of time from the time of the deictic center to the retrospective periods in the text. This last chapter is a collection of short retrospective episodes presented 
either in the simple past or the past perfect tense. All these episodes are sequenced with the help of time adverbials and other time-indicating devices: in the meantime, now, then. The sign of returning to the interrupted time continuum is the adverbial now, which indicates that the narration again occurs about the year 1965, as denominated in the title of the chapter. The exact time indication is given: It was already four o'clock. The dialogue following this time indication is perceived as happening at this time. However, in the dialogue itself, time shifts constantly forward and backwards again leaving the reader to unite different events in a time-linear order.

\section{CONCLUSIONS}

Toni Morrison in "Sula" does not follow a traditional linear narrative. Narration seems to move forward in time but there are multiple instances of retrospection and prospection, expressed through the deictic center of the narrator and the characters. Tense, time adverbials and semantics of the situation are complimentary means for creation of this intricate time fabric of the novel.

Tense indicators of the deictic center prove to have particular importance in reconstructing the sequence of events in those cases, wherever time adverbials are omitted.

In most cases, a characters' deictic center is rendered in dialogues unfolding at the spoken moment. On the other hand, the narrator's remarks are predominantly in the past tense. The analysis reveals that the past perfect tense is rarely used in the novel. The narrator usually alludes to past - her own deictic center - using the past tense; present, past and future tenses prevail in dialogues, with few instances of the past perfect tense traced.

An opposite phenomenon is also observed: the narrator's time deixis is in the present, but the character's events are recounted as happening during different periods of the past. Thus, the alteration of two temporal realities take place: the narrator's deixis and the character's one. The shifting of deictic center and time reference is on numerous occasions connected with the change of the micro-theme of the narration. Usually, a new motif is signaled by time adverbials, thus they carry a significant semantic load.

Even though the title of each chapter stipulates episodes within a specific year, the events do not predominantly coincide with the time indicated in the title, i.e. the deictic center of the chapter. The narrator inserts retrospective and prospective episodes constantly and often shifts the micro-theme. 
The duration of events in the text is defined with different precision ranging from several years to an hour, that being determined by the author's purpose to reveal details which are relevant to the structure of the plot and the artistic purpose.

Instances of prospection are not numerous. However, the text abounds in retrospective episodes containing time adverbials. The retrospection in "Sula" performs the following functions: connects past events with the current time of the narration, presents information from the past for a deeper understanding, gives the reader an opportunity to think over the current events in a new light, intensifies the reader's attention on particular parts of the text.

The narrator maneuvers present and distal past in a succession of scenic records, works backwards and forwards until the complete portraits of characters finally emerge at the end of the book. The intricate character of arranging of the events is perceived only by tracing them through the novel and reconstructing their chronological sequence. Events, like varicolored puzzle pieces, should be assembled to form the whole picture. The past is constructed from several sources and presented in fragments which are placed each time at the proper moment of the current process for maximum effectiveness.

The analysis proves that in contrast to real objective time, figurative time is non-linear, interrupted, non-homogenous and has anomalies moving forward and backward.

\section{Sources}

Morrison. T. Sula. London: Vintage Books, 2005. Print.

\section{Works Cited:}

Bouson, Brooks J. Quiet As It's Kept: Shame, Trauma, and Race in the Novels of Toni Morrison. Albany, N.Y: State University of New York Press, 2000. Print.

Dancygier, Barbara. "Proximal and Distal Deictics and the Construal of Narrative Time”. Cognitive Linguistics, vol. 30 (2), 2019: 399-415. Web. 2 May 2021.

Fetters, Cassandra. "The Continual Search for Sisterhood: Narcissism, Projection, and Intersubjective Disruptions in Toni Morrison's Sula and Feminist Communities". Meridians 1 March 2016; 13 (2): 28-55. Web. 2 Feb. 2021.

Grundy P. Doing Pragmatics (4 ${ }^{\text {th }}$ ed.). London: Routledge, 2019. Print. Halliday, M.A.K., and Jonathan J. Webster. Text Linguistics: The How and Why of Meaning. London: Equinox, 2014. Print. 
LeClair, Thomas. "The Language Must Not Sweat". A Conversation With Toni Morrison.1981.https://newrepublic.com/article/95923/the-languagemust-not-sweat. Web. 24 Feb.2021.

Lopez-Ramirez, Manuela. "El veterano con neurosis de guerra en las novelas de Toni Morrison Sula y Home." Atlantis, revista de la Asociación Española de Estudios Anglo-Norteamericanos, vol. 38 (1), 2016: p. 129+. Gale OneFile: Informe Académico. Web. 1 Feb. 2021.

Lyons, John. Semantics. Cambridge: CUP, 1977. Print.

Kitanovska-Ristoska, Elena. "The discourse of motherhood and motherdaughter relationships in the novel Sula by Toni Morrison". Thesis, 9 (2).2020: 301-317. Web. 2Feb.2021.

Kpohoue, Ferdinand. "Emasculation of male characters as seen through Sula by Toni Morrison." International Journal of Applied Linguistics and English Literature [Online], 7.2 (2018): 20-25. Web. 2 Feb. 2021

Ladin, Joy. "It Was Not Death": The Poetic Career of the Chronotope". Bakhtin's Theory of the Literary Chronotope: Reflections, Applications, Perspectives. Eds. Nele Bemong, Pieter Borghart, et al. Gent: Academia Press, 2010. 131-156. Print.

Mambrol, Nasrullah. "Analysis of Toni Morrison's Sula". Literary Theory and Criticism.2021. https://literariness.org/2021/01/19/analysis-of-toni-morrisons-sula/. Web. 15 May.2021.

McDowell, Deborah E. "Boundaries; or, Distant Relations and Close Kin -Sula." The Changing Same": Black Women's Literature, Criticism, and Theory. Ed. Deborah E. McDowell. Bloomington: Indiana University Press, 1995. 101117. Print.

Nissen, Axel, and Toni Morrison. "Form Matters: Toni Morrison's 'Sula' and the Ethics of Narrative." Contemporary Literature, vol. 40, no. 2, 1999, pp. 263285. JSTOR, www.jstor.org/stable/1208913. Web.1 Feb. 2021.

Peach, Linden. Toni Morrison. Macmillan Press LTD, London: Macmillan Press Ltd, 1995. Print.

Sanders, Jose, and van Krieken, Kobie. "Travelling through narrative time: How tense and temporal deixis guide the representation of time and viewpoint in news narratives". Cognitive Linguistics, vol.30, no. 2, 2019, pp.281-304. Web. 28 Feb.2021.

Tardy, Christiane M., Swales, John. M. "Form, text organization, genre, coherence, and cohesion". Handbook of Research on Writing: History, Society, School, Individual, Text. Ed. Charles Bazerman. Taylor and Francis, 2009: 693-714. Print.

Volkova, Svitlana. "Reverse Perspective as a Narrative Technique in Amerindian Prosaic Texts". Lege Artis: Language Yesterday, Today, Tomorrow, 2016; vol. 1 (1): 359-394.Web. 02 May 2021. 


\section{ВРЕМЕННЫЕ КООРДИНАТЫ И ДЕИКТИЧЕСКИЙ ЦЕНТР В ТОНИ МОРРИСОН «СУЛА»}

В настоящем исследовании рассматривается роль лексических и грамматических средств, воздействованных в процессе построения и поддержания хронологической организации текста.

Данные средства препятствуют нарушению континуума текста в эллиптическом фрагментарном повествовании новеллы «Сула» лауреата Нобелевской премии Тони Моррисон. В новелле повествование движется вперед и назад, отклоняясь от линейной хронологической последовательности событий.

«Сула» (1973) - один из первых романов о чернокожих феминистках в Соединенных Штатах. Нынешние социальные движения возобновили интерес к этой истории. Сама автор охарактеризовала новеллу как "треснувшее зеркало», части которого должен собирать читатель. Методология исследования основана на качественном подходе к решению поставленной цели, которая реализуется при помощи описательного, аналитического и структурно-нарратологического методов.

За анализом всего текстового корпуса романа следует описание полученных данных с выделением преобладающих темпоральных средств, используемых в ретроспекции, проспекции, дейксисе, континууме повествования и в общей структурной организации сюжета.

В статье подробно описаны повторяющиеся средства, связанные с хронологической организацией текста - дейктический центр, употребление определенного глагольного времени, наречия времени и общая семантика ситуации.

Исследование может способствовать развитию конкретных аспектов хронологической организации текста в общей теории лингвистики текста. Наши наблюдения могут найти применение в обучении практическому литературному анализу и творческому письму, способствовать определению средств временных координат и развивать у учащихся навыки анализа и реконструкции фрагментированного текстового континуума.

Ключевые слова: хронология нелинейного повествования, временные координаты, дейксис. 